\title{
THE CIRCULATION OF THE ENDOLYMPH
}

\author{
STACY R. GUILD \\ Department of Anatomy, Lniversity of Michigan \\ ONE FIGURE
}

INTRODUCTION

On theoretical grounds alone, a continuous process of renewal and removal of endolymph seems more probable than does a retention of the fluid present. For the metabolic processes of the tissues of those parts of the walls of the membranous labyrinth which are not closely related to blood vessels a circulation of endolymph would appear to be quite essential. The experimental work reported in this paper was planned as an attempt to determine whether such a circulation exists or not and, if so, something definite with respect to the normal movements of the endolymph and the places at which and the manner in which it leaves the membranous labyrinth. The suggestion was made by Dr. G. Carl Huber, director of the department, that the application of the methods used on the cerebrospinal fluid by Weed ('14 et seq.) and by Wegefarth ('14) on the aqueous humor might be applicable to this problem, and this has been done with results which indicate that the circulation of endolymph is quite comparable to that of cerebrospinal fluid and of aqueous humor.

In the course of the experimental study certain morphologic features were observed which are of themselves of importance and which are also confirmatory of the conclusions arrived at by the strictly experimental method. These morphologic observations upon the ductus and saccus endolymphaticus were prepared for publication first because it was found that a proper description of the experimental re- 
sults required the use of terms descriptive of structural facts not previously recorded. In this paper frequent references will be made to both the text and the illustrations in this other article (Guild, '27) in order to avoid undue repetition.

This work and the results were reported briefly at the Buffalo and Cleveland meetings of the American Association of Anatomists (Guild, '24, '25).

\section{HISTORICAL}

The problem of the possible communications of the fluids of the internal ear with the other body fluids has been studied for as long as the presence of these labyrinthine fluids has been known. Cotugno (1760) discovered the membranous aquaeductus vestibuli by observing that mercury flowed through it, and he expressed the view that possibly fluid entered the labyrinth thus. Boettcher ('69) established the actual presence of and described the membranous aquaeductus vestibuli and its connections, and thus ended the century-long dispute that followed Cotugno's report. He regarded it as probable from the structure that endolymph was formed by the saccus and flowed through the ductus to the rest of the membranous labyrinth. Hasse ('73), however, on the basis of what he himself later (Hasse, '81) admitted were incorrect observations of communications with the 'epicerebral' spaces in axolotl, birds, and mammals, guessed that the endolymph communicated through these: with the cerebrospinal fluid, being thus similar to the probable communication with the exterior in the selachians. Key and Retzius ('75) found that when fluid was injected under pressure into the meningeal spaces it did not enter the saceus and also that upon injecting the saccus directly by means of a small cannula inserted through the dura the use of considerable pressure gave no evidence of openings in its wall. Rüdinger ('87) reported in fetuses of several mammalia, including human, communications between the saccus endolymphaticus and surrounding 'lymphatic' channels by way of openings in the ends of what he termed 'accessorische 
Kanälchen' and also through 'scharf abgegrenzte Lücken' in the fundus of the sac; he regarded these openings as the place of outflow of the endolymph. His observations have not been confirmed, and Sterzi ('09), Siebenmann ('19), and Guild ('27) deny the presence of either type of opening in the adult. While I believe the work here reported proves that this is the real direction of flow, Rüdinger's guess was founded on a mistaken idea of structure and he had no experimental basis. Iwata ('24) has recently stated that in the bats there are openings in the wall of the saccus into surrounding spaces and thinks that the endolymph flows out through these. The criticisms of Rüdinger's paper apply to this also.

The uncertainties of modern views are well expressed by the following quotations. Siebenmann ('19) says: "Der Saccus endol. wird in der Hauptsache als rudimentäres Organ und-wohl mit Unrecht--auch als Ausweichstelle für die endolymphatische Flüssigkeit betrachtet; zu dem ist die Ansicht geäussert worden, dass er die Bildungs- resp. Ersatzstätte der Endolymphe repräsentiere. Meine Untersuchungen ergeben aber, dass letzteres sehr unwahrscheinlich ist." And Kolmer ('23) says, in his section in the recent Hand buch der Neurologie des Ohres, edited by Alexander, Marburg, and Brunner (p. 119): "Der Ductus endolymphaticus, . . . erscheint bei den höheren Wirbeltieren eher als ein rudimentäres Organ immerhin mag er einen Druckausgleich gegen die Schädelhöhle hin vermitteln."'

Fleischmann ('18) secured only negative results in his attempts to locate the source of the fluids in the labyrinth by intravital staining after injections of trypan blue and isamin blue, and concluded (p. 202) : “. . . . dass mit grosser Wahrscheinlichkeit im inneren Ohr keine Sekretion von Labyrinthwasser erfolgt, und dass somit Endolymphe und Perilymphs voraussichtlich keine selbständige Sekrete sein, sondern aus dem Liquor cerebrospinalis stammen werden." The details of the implications of the above conclusion are not suggested. The spread of the bacteria injected through 
the round window by Blau ('12) and the numerous records of clinical cases of labyrinthitis give no information as to the normal movements of the fluids in the internal ear. Likewise, the changes in the labyrinthine fluids and tissues which Wittmaack ('16, '19) brought about by placing solutions of various salts and acids in the middle ear do not throw any light on the movements of these fluids; and the technique of his injections of the semicircular canals in chickens would have forced the granules used directly to the locations where they were later found.

METHOD AND MATERIAL

The experimental attack of the problem was by the general method of placing in the membranous labyrinth of living animals some fluid which could be left under conditions as nearly normal as possible for a time sufficient to permit it to be carried from the site of injection by any currents present in the endolymph, and then, after autopsies at various time intervals, the location of the injected material was determined. Thus it was hoped to learn whether a flow does occur and, if so, what its pathway is. As stated in the introduction, the general methods used by Weed and Wegefarth for the study. of the movements of the cerebrospinal fluid and of the aqueous humor, respectively, have been utilized as a basis for the attack of this problem. The small size of the parts of the membranous labyrinth and their anatomical relationships from the standpoint of operative accessibility render the actual experimental procedures for the study of the circulation of the endolymph more difficult than for the other fluids. The 'mechanics of a closed box' apply to this problem, so that in order to experimentally introduce fluid into the labyrinthine systems it is, of course, necessary to replace rather than to try to increase the total content. The method of having two openings and injecting through one and permitting the endolymph to escape through the other was selected as offering a better chance of success than the method of withdrawal followed by replacement through a 
single opening. By this method selected the trauma due to the production of excessive intralabyrinthine pressures during the injection can be minimized, if not entirely avoided.

For mammalia the most feasible approach to any part of the membranous labyrinth for the purposes of this experiment appeared to us to be through the external wall of the cochlear duct in the forms in which the cochlea projects markedly into the middle ear. Because of previous familiarity with the exact relations in the guinea-pig (Cavia cobaya), this animal was selected from the group in which this condition occurs. In this animal the width of the external wall of the cochlear duct, i.e., the distance between the attachments to the spiral ligament of the basilar membrane and the vestibular (Reissner's) membrane, is approximately $0.4 \mathrm{~mm}$. in the lower turns. Since the location of this relatively narrow zone cannot be determined exactly from the surface of the bony cochlea in the living animal the use of holes as large as the full width would be almost certain to overlap in one direction or the other, but it seemed possible that if an attempt were made to drill holes of a diameter of not more than half the width of the outer wall of the cochlear duct, some of them should be so placed as to open into the cochlear duct without breaking through into either scala vestibuli or scala tympani. The question of a method of drilling such small holes in the cochlear wall offered some difficulties, since any drill with a diameter of but $0.2 \mathrm{~mm}$. would be too flexible if of a length sufficient to pierce the bony wall. Two things were found that answer the purpose; they are, $a$ ) the smallest-sized dental reamers and, $b$ ) fine cambric needles with the points ground flat on two sides. The reamers were operated with a dental motor and the needles were placed in rounded wood holders and used by direct rotation with the fingers. With both the drilling was stopped as soon as the end of the point pierced the inner surface of the bone sufficiently to permit the introduction of the tips of the glass capillary pipettes which were used for the actual injection of the fluid. The smallest hypodermic needles are too large to use for this 
work. Sometimes the point of the drill completely pierced the spiral ligament and stria vascularis as well as the bone, and sometimes the final penetration of the soft parts had to be done with the glass pipette. Since by this method there was not an actual removal of the relatively thick layer of soft tissues, their collapse after withdrawal of the pipette aided in the closure of the injection site later. The hole in the bone was carefully filled with a suitable amount of the 'bonewax' commonly used in surgery, and quite successful occlusion was routinely secured by this means.

A mixture of equal parts of potassium ferrocyanide and iron-ammonium citrate in aqueous solution was the fluid selected for the experiments. Even when injected into the subarachnoid space in large quantities, Weed stated that a 1 per cent solution ( 0.5 per cent of each) of these salts is non-toxic, so that for the minute amounts that can be used in the labyrinth the possible toxic effects are negligible. A 1 per cent solution was used in all but four animals with which a 4 per cent solution was tried. This stronger solution is, of course, quite hypertonic and its toxicity unknown.

The procedures with each animal were as follows. After examining for possible middle-ear infections the hair about one ear (the left one was routinely used) was trimmed with scissors, then the animal was anesthetized with ether and the operative field shaved. The guinea-pig was then fastened on an animal board with the left side of the head turned upward. Skin ineisions extending downward and forward and downward and backward from the external auditory meatus were joined below the pinna, the cartilaginous part of the external auditory canal was dissected free and completely removed, the rest of the soft tissues over the bone of the tympanic bulla were retracted and a sufficient amount of the bulla removed with small bone forceps to expose the projecting part of the cochlea on the medial wall of the middle ear. Hemorrhage was controlled by the usual surgical methods and was checked as completely as possible before proceeding further, since the cochlea lies at the bottom of the exposure and is 
therefore quickly covered with any fluid that accumulates. Using one or the other of the methods of drilling that have already been described, holes were made through the middle of the projecting parts of the basal and of the second turns of the cochlea (first and third half-turns of my usual terminology). The external wall of the cochlear duct can sometimes be approximately located through the bone by its pigmentation and vascularity, but in some guinea-pigs it cannot be determined thus, and in all cases the groove on the surface between turns served as a landmark to aid in placing the holes. Freshly prepared solution of potassium ferrocyanide and iron-ammonium citrate as above mentioned was injected with a suitable-sized glass capillary pipette through one of the openings; the endolymph flows from the other opening readily as the injection is attempted if the soft tissues have been pierced; when the endolymph could not be seen flowing from the other opening, the pipette was withdrawn from the first hole and injection attempted through the other; this usually succeeded in establishing communication between the holes. (This part of the work is best done under a dissecting binocular with low magnification.) Injection was continued until the fluid flowing from the counteropening could be seen by its color to be the injection fluid. A rough approximation of the capacity of the cochlear duct of the guinea-pig for this portion between the two holes shows it to be somewhat less than $0.5 \mathrm{cu} . \mathrm{mm}$., so that the amount of fluid which can be retained when injected thus is about equal to this very small quantity. Very slight pressure, applied by using the mouth, was employed for injecting; a piece of very flexible rubber tubing permitted this to be done without disturbance of the pipette by the transmission of the head movements of the operator. Hemorrhage from the small blood vessels in the spiral ligament and the stria vascularis is, of course, unavoidable by this method; it was not sufficient to interfere at all with the injection procedures and, in fact, observation of a movement of blood-stained fluid away from the counteropening was usually the first definite proof 
that complete penetration had been effected. The red blood cells which entered the labyrinthine cavities from these hemorrhages served as an injection of particulate matter, and the later location of these cells was recorded as well as that of the injected solution.

After completion of the injection of the solution used both holes were filled with surgical bone-wax placed with the tip of a small wooden applicator. After observation for several minutes, to see if the occlusion was good, all clots and fluids in the field of operation were carefully wiped out and the skin flaps drawn together with a few stitches. The wound was covered with a pad of gauze held in place with adhesive tape applied so as to resist the scratching efforts of the animal later. The total time of anesthesia was usually about one hour.

The animals were killed at intervals of from forty-five minutes to forty-four hours after the injection. The histologic technique employed was planned with the primary object of locating the final position of the injected fluid rather than of giving good preservation of structural detail. Fixation was by either 10 per cent or 20 per cent formalin to which was added either 1 per cent or 2 per cent of hydrochloric acid to cause precipitation of ferric ferrocyanide (Prussian blue) from the injected fluid. In the majority of cases the animal was killed by an overdose of ether, then a mass ligature was placed about the neck to retain the blood in the vessels of the head as far as possible, the vault of the cranium carefully removed, and the operative wound opened to permit access of the fixation fluid. In order to disturb the blood about the internal ear as little as possible, the brain was not removed until after immersion in the fixing fluid for a few hours. In order to secure a more prompt precipitation of the injected fluid, a vascular injection of warm fixing fluid was employed for eight animals. Since structural detail was not especially needed, paraffin embedding was used instead of celloidin, because of the greater ease in mounting serial sections. Serial sections of the entire labyrinth were made, usually at $20 \mu$, 
which is thin enough to permit of the accurate determination of the Prussian-blue granules. The plane of sectioning was approximately horizontal and as nearly parallel to the modiolar axis of the cochlea as possible. Carmine was selected for staining, as it affords a good color contrast to the blue precipitate and thus renders the observation of granules easier and helps to prevent overlooking them in study of the sections. For most of the material this was used in the form of a bulk stain with borax carmine.

Several of the unoperated right labyrinths were saved and prepared as controls of the histologic technique. The author's collection of guinea-pig labyrinths by good histologic methods was freely used for comparison when needed.

Besides the dead animals used for the development and testing of operative procedures, a total of twenty-five such experimental injections of the endolymphatic channels was attempted; the animals used have been designated in the order of the experiments as A 1 to A 25. From these, twenty operated labyrinths have been prepared into serial sections and used for microscopic study. Of the other five, A 1 and A 2 were injected with methylene blue and used for binocular dissection in an attempt to get some idea of the rapidity of spread of injected material; A 14, injected with the usual solution, was likewise used for immediate dissection; the endolymphatic sac of A 15 was dissected out and prepared separately, and the entire group of sections of A 12 were lost before they were studied.

The guinea-pigs used ranged in weight from 230 to 460 grams; age data were not available.

DESCRIPTION AND DISCUSSION OF RESULTS

As each series of sections was studied, a careful record was made for each part of the whole labyrinth of the presence or absence of, and, if present, the amount and exact location of, granules of Prussian blue and also of blood and other types of free cells. The complexity of the internal ear makes such a detailed record of the condition of its parts for twenty 
specimens quite extensive even when recorded in tabular form. This detailed tabulation, to which constant reference has been made in my own study of the material, is much too large to permit of publication as a whole. The information might be presented for each animal in the form of separate protocols, but the value of this does not justify the space that would be required, so that the findings will be presented only as summaries of the various features.

In the first place, a detailed study was made of each site of injection, in order to learn exactly what was done in each one. The size of each hole in the bone was determined for two diameters; for the plane of the sections by a micrometer ocular, and for the plane at right angles to this by counting: the number of serial sections included. The average for all forty holes is $0.16 \mathrm{~mm}$., and with the exception of two holes all were less than $0.24 \mathrm{~mm}$. in diameter and thus well within the limit of the approximate distance of $0.4 \mathrm{~mm}$. between the attachments of the vestibular and of the basilar membranes to the spiral ligament in the regions drilled. The location of the hole in the bony wall with reference to the external wall of the cochlear duct was also recorded; the self-explanatory terms 'Correct,' 'High,' 'Low,' 'Correct to High,' and 'Correct to Low,' being used. For the basal turn fourteen holes were 'Correct,' 5 were 'Correct to Low,' and 1 was 'Low,' for the second turn 14 were 'Correct,' 5 were 'Correct to High,' and 1 was 'High.' This makes a total of twenty-eight out of forty holes correctly placed; this does not, however, represent the correctness of the placing of the fluid introduced, but simply of the location of the drill site with reference to the soft parts. Of the twenty basal turn holes, the spiral ligament was correctly penetrated in eighteen cases; in one case the hole in the spiral ligament opened into both cochlear duct and scala tympani, and in the 'Low' position bony hole into the scala tympani only. But the sections also showed that in these basal turns there had been nine cases of piercing or breaking of the vestibular membrane and three of piercing of the basilar membrane. For the holes in the 
second turn the record is even worse, as it is complicated by the unexpected ease with which the spiral ligament becomes detached from the bone toward its 'upper' or scala vestibuli border. There were fourteen cases (ten of them with the bony hole 'Correct') in which the spiral ligament had been pushed loose so that the hole in the bone communicated with the scala vestibuli; of these fourteen there were nine in which the desired opening had also been made into the cochlear duct. There were only five cases in which an opening into the cochlear duct had been made in the spiral ligament of the second turn without it also having been thus pushed loose at its 'upper' border. In one case the hole made in the spiral ligament of the second turn opened directly into both cochlear duct and scala vestibuli. In the second turns the vestibular membrane had been perforated five times; there were no accidents to the basilar membrane.

A check of the detailed records of these openings to determine into which cavities the fluid introduced might have gone, irrespective of how, gives the following summary. In sixteen cases there were two openings made into the cochlear duct, in three cases only one opening, and in one animal the cochlear duct was not entered at all. Of the sixteen with two openings there is only one labyrinth with both openings exclusively into the cochlear duct with no opening of any nature into the perilymphatic spaces. There are fourteen eases with two openings of some sort into the perilymphatic spaces and five others with one opening. Of the twenty labyrinths, there are eleven with two openings of some nature into both cochlear duct and perilymphatic spaces.

These facts regarding the actual openings made at once raise the question as to whether or not all the conclusions that can be drawn are invalidated by the presence of the communications between the endolymphatic and perilymphatic spaces. Did these connections so upset the normal course of the fluids that it is not permissable to draw even tentative conclusions from the observations of the final location of the introduced fluid? Because of certain facts that 
will become apparent as the description proceeds, I believe that the evidence is not thus invalidated, but the possibilities brought about by these abnormal communications must be constantly kept in mind in all considerations of these experiments. The question can only be finally answered by the study of a sufficiently large series in which no communications exist.

The most striking fact observed upon study of the material is that in sixteen out of the twenty-one cases studied with the microscope (this includes A 15, of which only the endolymphatic sac was sectioned) there are Prussian-blue granules not only in the lumen of the saccus endolymphaticus, but also embedded in a certain part of its epithelial wall. The part in which they are located is that which I have described as characterized by the presence of columnar epithelium, crypts, and processes, with a subjacent well-vascularized areolar tissue, and for which I have suggested the term 'pars intermedia' of the 'saccus endolymphaticus proprius.' The granules are present in the epithelium of both the erypts and of the main part of the wall of this region. Figure 1 is a sketch which shows the location of the granules of Prussian blue in a particular part of one section. As may be seen, the granules are sometimes isolated and sometimes are massed as though the fluid from which they have been formed was more concentrated in certain parts. In one there has occurred also a diffuse staining of some of the cells of the wall; this is one of those in which the 4 per cent solution was used. In this same case and in two others with much blue in the pars intermedia there are also some granules of precipitate in the epithelial wall of the pars distalis of the saccus. Omitting the animal in which the fluid injected entered the perilymphatic spaces only (A 10), this makes sixteen out of twenty, or 80 per cent of the possible cases. Three of the four cases without blue granules in the walls of this part of the endolymphatic sac are in the group of shorter-elapsed times; A 9 was killed after only forty-five minutes, and there are no blue granules even in the lumen of the canalis re- 
uniens; A 18 was killed after two hours and there are blue granules in the lumen of the canalis reuniens and sacculus, but not in the ductus endolymphaticus; A 21 was killed after four and three-quarters hours, by which time others had blue granules in the endolymphatic sac, but it had no granules beyond the canalis reuniens. The remaining negative case is A 13, killed after seven hours and fifty minutes; there is only one opening into the cochlear duct, and without a counteropening this may have permitted so little fluid to enter as

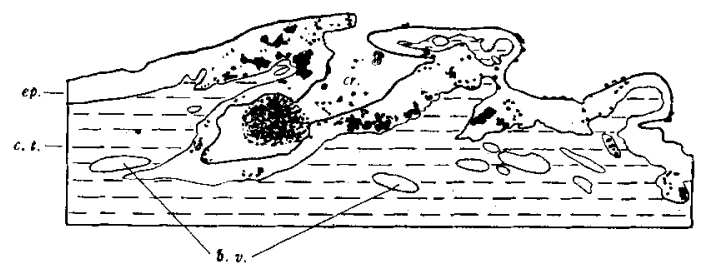

Fig. 1 Outline sketch of part of wall of pars intermedia of the saccus endolymphaticus proprius of guinea-pig A 4, left labyrinth, slide 9, row 2 , section 3 . This animal was killed twenty-one hours after a 1 per cent solution of equal parts of potassium ferrocyanide and iron-ammonium eitrate had been injected into the ductus cochlearis; fixation by 10 per eent formalin plus 1 per cent $\mathrm{HCl}$. In order to permit the Prussian-blue precipitate to be demonstrated in the sketeh without the use of a colored illustration, the epithelium and connective tissue have been shown in outline only. This figure should be compared with figure 6 of the author's paper on structure of this region. ep., epithelium, in outline; c.t., connective tissue, shown with horizontal hatehing; b.v., two of several small blood vessels in sketch; cr., a crypt of the saceus. All solid black dots and masses represent the ferric ferroeyanide present.

to be a plausible explanation for the absence of sufficient fluid in the wall of the saccus to yield a precipitate.

In most of the labyrinths with blue granules in the wall of the pars intermedia of the saccus there were also granules in the lumina of the canalis reuniens, the sacculus, and the ductus endolymphaticus, as well as in the lumen of the saccus endolymphaticus. Even without this evidence of the route taken to reach the saccus wall, the only plausible explanation for the presence of the Prussian-blue granules in the epithelial wall of the pars intermedia in so many cases is that the injected fluid has passed, without continued injection pres- 
sure, from the ductus cochlearis through the canalis reuniens into the sacculus, and from this through the ductus endolymphaticus into the saccus endolymphaticus, where it has passed into the wall of a portion which is morphologically differentiated (Guild, '27) from the rest of the membranous labyrinth. That the injected fluid was passing through the wall, rather than simply into it, seems probable from the fact that the areolar tissue surrounding this part of the wall contains numerous blood vessels; but the direct evidence on this point is very scanty, since there were blue granules present beneath the epithelium in only four cases, and in only two of these was the small amount observed near blood vessels. No granules were found in these blood vessels near the saccus; but the chance of finding such is slight, in view of the very small amount of fluid injected and the rapidity with which any of it that did reach the blood stream would have been carried away.

The hypothesis which best explains the experimental observations just recorded is that the endolymph in the guinea-pig flows from the region of the cochlear duct toward the endolymphatic sac via the intervening parts of the membranous labyrinth and that the wall of the pars intermedia of the saccus is a region of outflow of the endolymph, and that the injected fluid was carried along with the endolymph. Diffusion offers a possible explanation of the spread of the injected fluid, and that it may account in part for the spread of the 4 per cent solution is indicated by the fact that only in the four cases where this stronger solution was used are any Prussian-blue granules present in the utriculus or membranous semicireular canals, although the patency of the utriculosaccular duct can be demonstrated in each series of sections. But the small caliber of the canalis reuniens and of the ductus endolymphaticus does not favor this as a satisfactory explanation of the whole movement, and diffusion does not account in any way for the presence of Prussian-blue granules in only the wall of a restricted part of the saccus. Besides the cells which are a normal content of the saccus 
(fig. 12 of the article on structure) there were also frequently present in these operated labyrinths red blood cells, which from their distribution are readily accounted for as being from the hemorrhage at the injection sites. Only an actual movement of the fluid in the membranous labyrinth can account for the transportation of these cells to the saccus. The possibility is, of course, always to be considered that this hemorrhage and the exudation resulting from the trauma at the sites of injection has had the effect of causing an abnormal movement of the fluid, as well as the accidental communications with the perilymphatic channels which have been described above. However, it is a physical impossibility for fluid in any quantity to pass from the ductus cochlearis into the saccus endolymphaticus through the intervening channels by any conceivable process other than diffusion without a simultaneous escape of an equal amount from the saccus itself. That the departures from normal conditions in the region of the injection sites can have caused a development of an abnormal mechanism of outflow in a region as remote as the saccus endolymphaticus seems rather improbable. In fact, the abnormal communications with the perilymphatic spaces undoubtedly did make possible an escape of endolymph also via any route which is normal for the perilymph. The evidence from these experiments concerning the perilymphatic pathways will be considered later.

An important support of the hypothesis which has been formulated from these experiments is the fact of the presence of numerous cells of several types and of cellular debris as a normal content of the saccus endolymphaticus (Guild, '27). The place of entrance of these cells into the membranous labyrinth is unknown. On the assumption that they enter the endolymph at many parts of the walls of the labyrinth, their concentration in the one region must be interpreted as an evidence of a movement of the endolymph toward the saccus endolymphaticus, and the concentration in this region as due to the inability of the cells to escape with the fluid which has served to transport them. This is entirely analogous to the 
accumulation in the region of the arachnoid villi of particulate matter introduced into the cerebrospinal fluid. On the possible assumption that these cells have all entered the endolymph locally, i.e., directly into the saccus itself, the fact that they are numerous here and that cells of any kind are but very rarely observed in the cavities of the other parts of the membranous labyrinth is almost conclusive evidence that the endolymph does not flow from the saccus to the rest of the labyrinth in the guinea-pig; in other words, the saccus is not the source of the endolymph.

The objection of artificial conditions cannot be urged against the evidence afforded by the location of these cells, and in this connection certain facts of comparative anatomy are of interest. It has been well known for a long time that in many amphibian and in some reptilian forms the saccus endolymphaticus contains normally numerous small free erystals; these have been termed otoliths, otoconia, 'otolithenbrei,' etc., and there has been general agreement that these resemble the otolithic crystals of the membranes over the special neuro-epithelial areas in the particular animals. Many observers have recorded such crystals in frogs and salamanders; they were described in the geckos by Wiedersheim ('76), Rüdinger ('77), and others; and Breschet ('38), Retzius ('78, '81), Hellman ('98), and others have observed similar crystals embedded in a gelatinous mass in selachian forms in the enlargement of the ductus endolymphaticus near the superficial orifice. The fact of the presence in the endolymphatic sac of large amounts of particulate matter which apparently originated in the other parts of the membranous labyrinth may be interpreted as indicating a movement of the endolymph in these forms similar to that in the guineapig; i.e., the endolymph normally flows toward the saccus and passes through some part of its wall which will not permit the particulate matter to pass. The indications are certainly sufficient to justify a careful study of the movements of the endolymph in some of these forms with this as a working hypothesis; and unless such experimental work shows other- 
wise, I believe that the presence of this particulate matter in the endolymphatic sacs of some selachians, amphibians, and reptiles is reason for thinking that, whatever its source, the flow of endolymph in these forms is toward the saccus, and thus similar to that in the mammalia as represented by the guinea-pig.

The uniformly negative findings in the utriculus and membranous semicircular canals, except in the four cases with hypertonic solution, have already been mentioned. This is evidence that the endolymph does not usually flow toward the utriculus through the utriculosaccular duct; there is no evidence yet as to a possible movement in the reverse direction.

The lumen of the cochlear duct still contained in most of the animals at the time of killing a sufficient amount of the injected fluid to yield Prussian-blue granules upon fixation; this indicates that the rate of flow of endolymph away from the cochlear duct is rather gradual and agrees with the fact that three of the negative cases for the wall of the saccus are in the group of relatively short time intervals.

The foregoing description and discussion embodies the facts and deductions which appear to be of most significance, but certain other observations upon this material should be included also, in order to complete the record of the results, and are as follows.

Almost the whole extent of the spiral ligament was infiltrated with blue granules in three labyrinths and in parts other than adjacent to the injection sites in three more. In only one of these (A 5) was there any infiltration of the stria vascularis. In the three with extensive infiltration of the spiral ligament there are blue granules about the veins leading from it, and in one (A 9) there are some blue granules in the lumina of some of these veins. The route of entrance into the spiral ligament is not known; the fact that in all three cases with the most infiltration the records show much difficulty was encountered in establishing communication between the openings make it appear possible that the injected fluid spread at the time of injection directly along and around the 
vessels of the spiral ligament itself. The evidence is certainly not sufficient to indicate this as a normal pathway of escape for endolymph.

Gross breaking of the organ of Corti by the tip of the cannula at the time of injecting is a possible explanation of both cases in which blue granules were present in a small extent of the tunnel space and of the spaces of Nucl. In one labyrinth the nuclei of some outer hair cells and of some Deiters' cells were faintly outlined with blue, and in one in which the 4 per cent solution was injected there was some diffuse 'staining' of the surface of all the elements of the organ of Corti in the superior part of each turn, with the reticular membrane especially well outlined. In five cases there were some granules among the cells of Claudius, and the adherent granules were more numerous over these cells than over the principal part of the organ of Corti, although not more so than over the tectorial membrane. The tectorial membrane was infiltrated for more or less of its extent in nine animals, and in five the saccular otolithic membrane contained some blue granules. In view of the structure and attachments of both these membranes, it seems probable that this location of the granules is due to nothing more than diffusion.

The tissues of the limbus were infiltrated in one animal; apparently through the relatively small surface exposed to the scala vestibuli, and in this and in another case there were some blue granules near the nerve fibers in the osseous spiral lamina and in the spiral ganglion, but the granules are so frequently associated with small vessels as to make it seem probable that the real phenomenon is one of perivascular infiltration from the perilymphatic spaces into which much of the injected fluid passed in these particular labyrinths.

The sacculus usually contained many blue granules; these were for the most part free in the lumen or simply adherent to the walls. The partial infiltration of the otolithic membrane in five cases has been mentioned above and the probable significance stated. That portion of the wall of the sacculus which may be termed the region of the superior- 
posterior reflection, being that part with the medial side of the angle in contact with the wall of the utriculus near to or at the region of the anterior-inferior part of the macula utriculi, was so infiltrated as to give the effect of a staining of the cells in two of the four animals in which the stronger solution was used; and in two of the sixteen cases with isotonic solution there were scattered spots of similar appearance in this region. The greater part in each case was in the wall of the lateral side of the reflection, which rests against the membrane separating the vestibular perilymphatic space into a main cavity and a trabeculated part (de Burlet, '20). The possibility that this part of the wall is functionally differentiated from the rest is only hinted at by this evidence, and the observation is of very doubtful significance, but the fact that, in the four cases in which there was any infiltration at all of the walls of the twenty sacculi, this occurred in the same part of the wall should be kept in mind in future work.

\section{CONCLUSIONS}

A. From the data regarding the direction of flow of some of the injected fluid and of its place and manner of exit from the membranous labyrinth, from the structure of parts of the walls of the same, and from analogies with the circulation of the cerebrospinal fluid and the aqueous humor, a theory of the main features of the circulation of the endolymph has been formulated which I believe is sufficiently supported by the evidence to justify presentation at this time.

Source. Fleischmann's ('18) attempt to locate a source gave negative results, and I have no direct evidence; but if the endolymph flows from the cochlear duct as the evidence indicates, then there must be a source in the walls of this part of the membranous labyrinth. The stria vascularis is well adapted structurally for this purpose, and I believe it will be found to be the principal source of endolymph in this part at least. It may thus be tentatively considered as analogous to the choroid plexus and the secretory areas of the 
ciliary processes. I believe it probable that other sources of endolymph may also be present, but that in mammalia the greater part is formed by the stria vascularis.

Direction of flow. The endolymph in the cochlear duct moves toward the basal end and passes through the canalis reuniens into the sacculus, and from the sacculus through the ductus endolymphaticus into the saccus endolymphaticus. From the experimental evidence, this is the principal direction of movement of the fluid in these parts; for that in the utriculus and associated semicircular canals my unsupported opinion is that it most probably also flows toward the saccus endolymphaticus.

Place and manner of outflow. The endolymph passes through the wall of that part of the saccus endolymphaticus proprius which in the guinea-pig has been termed pars intermedia by the author. That the endolymph escapes through the walls of the saccus is indicated by the fact that the injected solution reached this part of the membranous labyrinth at all and also by the fact of the normal presence of free cellular material in the lumen of the saccus. The fact that the precipitate from the injected solution was present so. frequently in the walls of the pars intermedia indicates that this experimental fluid at least was escaping through this limited area, and the fact of the structural differentiation which I have recently described makes it a reasonable inference that this is a specialized region functionally. It is therefore regarded as the principal region of outflow, but it is possible that the wall of the pars distalis has the same function to a lesser extent, as in only three cases were granules observed in this part. The movement of endolymph through the wall of the saccus endolymphaticus is in a way comparable to that of cerebrospinal fluid through the arachnoid villi and of the aqueous humor through the tissues of the iridial angle.

B. As a corollary to this theory of circulation of the endolymph is the definite function indicated for the saccus endolymphaticus. In the review of the literature a brief summary 
of previously expressed views has been given; they have been quite different and all of them unsupported by any evidence. From the work reported above the saccus endolymphaticus has a very important function; it is the principal region of escape of the endolymph from the membranous labyrinth. The location of the Prussian-blue granules shows that this fluid movement occurs directly through the intact wall of a morphologically differentiated region, and, further, that the disputed special openings which have been described by Hasse, Rüdinger, and Iwata are not necessary for this function, even if their presence should be confirmed eventually. As to whether the rate of outflow is regulated by the wall or whether the process is one of simple filtration I have no evidence.

C. Without citing the literature on the question of the patency of the canalis reuniens in adult mammalian forms, attention may be called at this time to the fact that the flow of the injected fluid and of blood cells through the canalis reuniens from the ductus cochlearis to the sacculus is good evidence that it has an actual lumen in its whole extent in the guinea-pig. This is in complete agreement with the direct observation which I have made upon numerous series of sections of the guinea-pig labyrinth.

D. If my conclusions as to the circulation of endolymph are correct, then the results which would follow blockage of any part of this pathway are in all probability quite comparable to those which follow interference with the circulation of the cerebrospinal fluid. Thus, a failure to develop or to function normally of the wall of the pars intermedia of the saccus would result in a blocking of the outflow of the endolymph and a distention of all parts of the membranous labyrinth; an occlusion of the ductus endolymphaticus would result in distention of all parts except the saccus endolymphaticus, and an occlusion of the canalis reuniens would result in distention of the ductus cochlearis only. It seems entirely possible that such impairments do occur and that they may account for the conditions of abnormally distended parts of the labyrinth 
which have been occasionally reported. If this is correct, these labyrinthine conditions are comparable in causation to certain types of hydrocephalus. Those who have in their possession such material might find it worth while to study it from this viewpoint. The author has two series of sections of guinea-pig labyrinths which show very marked distention of the cochlear duct and of the sacculus; both were prepared especially for cochlear parts and, unfortunately, do not include the ductus and saccus endolymphaticus. In a report of the labyrinths from a very deaf twenty-year-old man who had congenital syphilis associated with chronic otitis media, Fraser ('23) has recorded, among other findings, the following (p. 779): "viii. Obstruction of the endolymphatic acqueduct as it passes thru the bone to the posterior cranial fossa. There is a catarrhal swelling of the lining membrane of the duct (Fig. 47 and 50). ix. Great dilatation of the membranous labyrinth, especially of the utricle, saccule, vestibular end of the endolymphatic duct (Fig. 40 and 50), and of the ductus reuniens. The basal and middle coils of the cochlea are also dilated (Fig. 33, 34 and 43)." There is no discussion that would indicate that Fraser considered these two findings as especially related to each other; but it seems very probable to me that the dilatation may have been a result of the obstruction. Careful reviews of the clinical histories in all cases of distention found in human material might eventually lead to a recognition of such conditions from the interference with normal functions.

\section{SUMMARY}

1. An experimental method of attack upon the problem of the circulation of the endolymph has been planned and carried out; it is essentially a modification of the method by which the circulation of cerebrospinal fluid and of aqueous humor was determined. A solution of potassium ferrocyanide and iron-ammonium citrate was introduced into the cochlear duct of living guinea-pigs through suitably small openings in the external wall of the part which projects into 
the middle ear. The animals were killed after intervals of from forty-five minutes to forty-four hours; by the use of acid in the fixation fluid, Prussian-blue granules were precipitated in situ from the injected fluid, the labyrinths were cut into serial sections, and the location of these granules determined by study with the microscope.

2. A detailed tabulation was made of the exact location of all Prussian-blue granules found in the sections; this is too extensive to permit of publication as such, so that the information afforded by the study has been presented in the form of general summaries.

3. The fact of most significance is that Prussian-blue granules were not present in the walls of most parts of the labyrinth, but in sixteen of the twenty possible cases there were blue granules in the morphologically differentiated part of the wall of the saccus endolymphaticus proprius.

4. The conclusion has been reached that there exists normally what may be termed a circulation of the endolymph; and the experimental and structural data are considered sufficient to justify the presentation at this time of what the author regards as the principal features of this circulation. The theory is briefly as follows: endolymph is formed by the stria vascularis, flows toward the basal end of the cochlear duct and through the canalis reuniens into the sacculus and from this through the ductus endolymphaticus into the saccus endolymphaticus, and leaves the membranous labyrinth by passing through the wall of the pars intermedia of the saccus into the numerous small blood vessels of this region.

5 . The other parts of the walls of the membranous labyrinth in which Prussian-blue granules were found in any of the preparations have been made a matter of record.

6. The observations indicate that the saccus endolymphaticus has a definite function, and is thus more than a rudimentary or vestigial part. It serves as the principal place of outflow of the endolymph; not, as some have thought, as the place of origin of endolymph. The escape of fluid is not through openings in the wall, but by direct passage 
through the layers of the wall, being thus comparable to the flow of cerebrospinal fluid through the arachnoid villi.

7. The pathway followed by the injected fluid is good evidence that in the guinea-pig a patent lumen extends the whole length of the canalis reuniens.

8. The possible interpretation of abnormal distention of the membranous labyrinth as an impairment of the normal pathway of the endolymph is discussed.

\section{BIBLIOGRAPHY}

BLaU, A. 1912 Experimentelle Studien über die Labyrinthitis. Arch. f. Ohrenheilk., Bd. 90, S. 1-32.

BowTTCHer, A. 1869 Über Entwickelung und Bau des Gehörlabyrinths nach Untersuchungen an Säugethieren. Verh. d. kais. Leop.-Carol. deut. Akad. d. Naturforscher, Bd. 35, S. 1-203.

1869 Ueber den Aquaeductus vestibuli bei Katzen und Menschen. Areh. f. Anat. u. Physiol., Jahrg. 1869, S. 372-380.

BREsCHET, G. 1838 Recherches anatomiques et physiologiques sur l'organe de l'ouie des poissons. Paris.

DE BURLET, H. M. 1920 Der perilymphatische Raum des Meerschweinehenohres. Anat. Anz., Bd. 53, S. 302-315.

Cotugno, D. 1760 De aquaeductibus auris humanae internae. Neapoli.

FleischmanN, O. 1918 Studien über die Herkunft des Labyrinthwassers. Arch. f. Ohrenheilk., Bd. 102, S. 193-203.

Fraser, J. S. 1923 The pathology of deaf-mutism. Laryngoseope, vol. 33, pp. 731-780.

GuLd, S. R. 1924 Experimental ovidence on the eireulation of the endolymph in mammals. Anat. Rec, vol. 27, p. 205.

1925 Strueture and normal contents of the ductus and saccus endolymphaticus in the guinea-pig. Anat. Rec., vol. 29, p. 358.

1927 Observations upon the structure and normal contents of the duetus and saecus endolymphaticus in the guinea-pig (Cavia cobaya). Am. Jour. Anat., vol. 39, pp. 1-56.

Hasse, C. 1873 Die Lymphbahnen des inneren Ohres der Wirbelthiere. Anat. Studien, Bd. 1, Heft 4, S. 765-816.

1881 Bemerkungen über die Lymphbamen des inneren Ohres. Arch. f. Ohrenheilk., Bd. 17, S. 188-194.

Hellaman 1898 Die Entwicklung des Labyrinthes bei Torpedo ocellata. Verh. d. deut. otol. Ges., 1898, S. $65-76$.

IwatA, N. 1924 Über das Labyrinth der Fledermaus mit besonderer Berücksichtigung des statischen Apparates. Aichi Jour. Exper. Med., vol. 1, pp. 41-173.

Key, A., UND Retzius, G. 1875 Studien in der Anatomie des Nervensystems und des Bindegewebes. Stockholm. 
Kolmer, W. 1923 Mikroskopische Anatomie des nervösen Apparates des Ohres. Handbuch d. Neurologie d. Ohres, herausg. von Alexander, Marburg, und Brunner, Bd. 1, S. 101-174.

Retzius, G. 1878 Zur Kenntnis von dem membranösen Gehörlabyrinthe bei den Knorpelfischen. Arch. f. Anat. u. Physiol., Jahrg. 1878, S. 83-107. 1881 Das Gehörorgan der Wirbelthiere, Bd. 1, Stockholm.

RüDINGER, N. 1877 Ueber den Aquaeductus vestibuli des Menschen und des Phyllodactylus europaeus. Zeitschr. f. Anat. u. Entw., Bd. 2, S. $214-230$.

1887 Über die Abflusskanäle der Endolymphe des inneren Ohres. Sitzungsber. d. math.-phys. Cl. d. kgl. hay. Akad. d. Wiss, zu München, Bd. 17 , S. $455-476$

SiebenManN, F. 1919 Anatomische Untersuchungen über den Saceus und Ductus endolymphaticus beim Mensehen. Passow's Beitr. zur Anat., usw. des Ohres, usw., Bd. 13, S. 59-64.

SterzI, G. 1909 Il sacco endolinfatico: Ricerche anatomiche ed embriologiche. Morph. Jahrb., Bd. 39, S. 446-496.

WEED, L. H. 1914 Studies on cerebrospinal fluid, No. III. The pathways of escape from the subarachnoid spaces with particular reference to the arachnoid villi. Jour. Med. Research, vol. 31, pp. 51-91.

1922 The cerebrospinal fluid. Physiol. Reviews, vol. 2, pp. 171-203. (The other work by this author is well summarized here.)

WEgEFARTH, P. 1914 The drainage of intraocular fluids. Jour. Med. Research, vol. 31 , pp. 119-147.

Wienersheim, R. 1876 Zur Anatomie und Physiologie des Phyllodactylus europaeus mit besonderer Berücksichtigung des Aquaeductus vestibuli der Ascolaboten im Allgemeinen. Morph. Jahrb., Bd. 1, S. 495-534.

WITTMAACK, K. 1916 Über die pathologisch-anatomischen und pathologischphysiologisehen Grundlagen der nichteitrigen Erkrankungsprozesse des inneren Ohres und des Hörnerven. Arch. f. Ohrenheilk., Bd. 99, S. $71-136$.

1919 Experimentelle Studien über die Beziehungen der Liquorsekretion und der Liqnorzusammensetzung zu einigen Erkrankungen des inneren Ohres. Klin. Beitr. f. Ohrenheilk. (Festsehr. f. Urbantschitseh), S. $675-760$. 